\title{
Examining Employees' Reward Preference and Its Association with Motivation to Work: A Case of Ethio-Telecom (Adama Branch)
}

\author{
Tesema Adinew
}

\begin{abstract}
Today most of the organizations would like to observe their employees feel motivated and ready to work hard, but they do not understand what truly motivates their employees at the work place. Reward is one of the motivational factors that help management to motivate and retain experienced workforce in an organization. But, there is a controversy among scholars concerned reward type that employees prefer to be motivated for their work. Therefore, the purpose of this study is to examine employees' reward preference in relation with motivation-A case of EthioTelecom (Adama branch). This study used descriptive research design with quantitative analysis and the study also used simple random sampling technique to draw a sample of 110 respondents from target population of 150 and the response rate of the study was more than $78 \% .5$ points Likert scale questionnaire was used to collect primary data from the respondents. Cronbach's alpha test was run to measure the internal consistency and the reliability of the questionnaire. This study used only primary data $\&$ the data analysis was done with the aid of statistical package for social science (SPSS) version 16.0. In order to test the strength of the relationship \& variance between each predictor the analysis was subjected to T-test and Chi-square test. The findings of the study show that absence of statistically significant difference among employees' reward preference based on their demographic characteristics except their age. Therefore, this study recommends that the management should provide both monetary and non-monetary rewards for its employees in order to motivate them for better performance. Finally, the study suggests that similar studies at others public institutions with a larger sample size should be undertaken \& seems appropriate to generalize this study.
\end{abstract}

Keywords: Non-monetary rewards, Monetary rewards and Motivation.

DOI: $10.7176 / \mathrm{EJBM} / 12-13-02$

Publication date:May $31^{\text {st }} 2020$

\section{Introduction}

In today's highly competitive environment reward has become an essential tool to attract, retain and motivate employees for better outcome. It is obvious that motivated employees are more productive in the workplace. Well rewarded employees feel being valued and treated so that they will be inspired to work harder and better (Sajuigbe et al. 2013). Lawler (1993) also said that if organizations treat their employees properly and have knowledge about what motivate their employees, they will reach their full potential.

Good and attractive reward is very crucial for employees' motivation. If not, unmotivated employees may not perform their tasks properly and it will eventually affect the image organization negatively (Hafiza et al. 2011). Reward could be tangible or intangible thing given to employees in recognition of their contribution or achievement (Munk, 2012).

So as to control individual's behavior organizations use different types of reward like, monetary and nonmonetary rewards. According to Luthans (2000) monetary rewards are pay-for-performance such as bonus, job promotion, salary increment, commission etc. On the other hand, non-monetary rewards are social recognition such as acknowledgment, certificate, meaningful work and genuine appreciation, participation in decision making etc (Cited by Qureshi et al. 2010). An organization performance is depending on its available workforce. Hence, to get better and quality outcome from them an organization must provide appropriate reward to their contribution. Since the success of any organization depends on its human resource, it is very critical for the organization to design and implement an effective reward system that can motivate and reduce factors that brings about dissatisfaction to their employees in the work place.

According to Kondalkar (2007, p. 99) motivation is defined as inner burning passion caused by need, wants and desire which propels an individual to exert his physical and mental energy to achieve desired object. Motivating employees is one of the most complex and challenging functions of a manager and a manager who does not know what and how to motivate his employees plans to fail (Smith 1994 cited by Okojie, 2009)

To motivate employee organizations can use different motivational techniques such as Financial \& nonfinancial rewards. However, identifying a reward type that can really motivate employees has become the most complex task for organizations (Carrell et al. 1995). Even though different motivation theories and specific studies have proved that reward is a very vital factor for employee motivation, they have failed to provide consistent findings as to which reward type is highly preferred \& linked to strong employee motivation. Some of those studies have shown that monetary rewards have a great potential in motivating employees in their work place and 
on the contrary, some other studies have argued that non-monetary rewards are the most effective instrument of employees' motivation. For example, Qureshi et al. (2010) underline financial rewards are not the most effective motivating factor rather they have a de-motivating effect on employees' motivation. On the other hand, Agarwal (2010) found that financial rewards are still the most crucial and decisive motivating factor for employees. Supporting the above statement, Armstrong (2007, p: 330) also justified that money is a powerful motivating force because it is linked directly or indirectly to the satisfaction of many human needs.

As explained above, the existing contradiction among the research findings on the area of rewards and motivation is an indication of lack of a clear picture with regarding to the knowledge and understandings of as to which reward type is highly preferred by employee in connection with motivation to work. Therefore, the objective of this study is to scrutinize and understand employees' reward preference and its relation with motivation to work place. The study would help an organization in designing, formulating and implementing an appropriate reward system, minimize the discrepancy and knowledge gap between the reward and motivation and it will also serve as an input for future research on the area.

\section{Research questions}

1. Is there any significant difference in employees' preference towards monetary and non-monetary reward?

2. Does preference towards rewards vary among employees based on their demographic characteristics?

3. Does level of motivation vary among employees based on their demographic characteristics?

4. What is the relationship between employees' rewards preference and motivation level?

\section{Objectives of the research}

- To identify whether there is any significant difference in employees' preference towards monetary and non-monetary reward.

- To identify whether preference towards rewards vary among employees based on their demographic characteristics such as age, gender, education qualification, marital status \& work experience.

- To know whether level of motivation vary among employees based on their demographic characteristics.

- To examine the relationship between employees' preference and motivation level.

\section{Review of related Literature}

\subsection{The relationship between rewards and motivation}

Reward system is comprising main components that include financial rewards benefits and non-financial rewards. There is a process of measuring and evaluating the work of the individuals so as to decide the level of employee benefits that need to be distributed. If an organization designs reward system properly in accordance with the demand of the employee it will motivate employees to put forth their efforts and it result in increments of employee's productivity and performance Okojie (2009).

An Organizations design motivation systems to energize employees to perform in the most effective way but also to retain and attract potential candidates (Lameck, 2011). Positive correlation between reward system and employee motivation exit and the study explained that effective reward system is very much essential for any organization because it can help to accomplish the business objectives by attracting and retaining effective employees. Effective rewards and motivation increase employee productivity. Therefore, this study has shown that level of motivation increases through either monetary or non-monetary rewards such as interesting work and good wages (Deeprose 1994 cited by Qureshi, Zaman and Shah, 2010)

Similarly, Muhammad, Maria \& Saqlain ( 2011) study conducted on the association between reward and employee motivation at the banking Sector of Pakistan shows that rewards and employee motivation have positive relationship and the chi-square results shows that there is association between motivational factors and demographical variables like gender, age, qualification, income and experience. However, there is no association between employee motivation and qualification while experience showed the least association with motivation and they determined motivational factors in orderly manner after the careful analysis of factors that affects motivation of Sympathetic help with personal problem.

Hafiza et al. (2011) also have found that there is a significant and positive relationship between monetary rewards and employee motivation. Besides, Arnolds \& Venter (2007) have indicated that managers have to take a notice of the rewards which their employees find motivational and interesting. If not done, a difference might occur between the strategies managers use to motivate employees and the motivational rewards these employees actually desire. This could lead to a situation in which employees and managers do not find common place in achieving organizational objectives. His study findings recommend that employees who find themselves in firms in which the reward systems are not designed as per the needs of employees, employees will perform what expected of them and will not be motivated to exert the extra effort that makes firms winning enterprises. Therefore, frequently assessing the rewards that motivate employees is very much important to all business firms.

According to Ude \& Coker (2012) study on incentive schemes, employee motivation and productivity in 
Organizations in Nigeria has proved that there is a link between incentive/reward schemes and employee motivation and productivity, if Incentive schemes properly designed and administered, can motivate employees and increase their productivity in organizations. Incentive schemes are fast becoming increasingly a popular technique in attracting, motivating, developing, and retaining employees in organizations. The study stated that experience has shown that organizations that provide effective incentives are more likely to have satisfactory job performance from employees. The major conclusion drawn from this study was that incentive schemes do have significant correlation with employee motivation and productivity in organizations in Nigeria. Finally, the paper recommends that management should identify the type of incentive/rewards scheme that is most motivating to employees, the incentives must be feasible for the organization to implement, organizations should therefore try to balance monetary /material considerations with non-monetary or non-material reinforcements to maximize job quality and quantity and Management should seek and obtain feedback on how employees recognize incentives. Feedbacks together with appropriate incentive schemes construct the strongest effect on job productivity.

\subsection{Influence of demographic characteristics on employees' reward preferences}

The study that examined determinants of employee benefit preference has shown that having deep understanding concerned the demographic characteristics of employees helps the organizations to design rewards program that can create unique value for their employees and ultimately it enable the organizations a take competitive advantage over competitors in the labor market (Chernyshenko \& Lawton, 2008). According to Nienaber et al. (2011) research on the relationship between personality types and reward preferences, employees' reward preferences are highly affected by their personal demographic characteristics. This study stated that reward preferences vary based on employees' demographic characteristics such as gender, educational qualifications, age, marital status and years of service. The study of Fisher \& Yuan ( 1998 cited in Snelgar et al. 2013) on what motivates employees also asserted that gender differences exist in reward preferences.

Nienaber et al. (2011) stated that women have a stronger favorite for monetary rewards than men. In addition to this, (Konrad et al. 2000) study on sex differences and similarities in job attribute preferences stated that men place greater emphasize on non-monetary aspects of rewards as motivators for better results than women. However, according to Kowalewski \& Phillips (2012 cited in Snelgar et al. 2013) study on preferences for performance based employee rewards discovered that there was not a significant difference in preferences between males and females on reward preference and the conclusion was drawn based on analyzing the data collected in terms of economic versus social rewards (or consequences). Economic rewards involved factors such as job security, good wages, promotion opportunities, monetary or gift card rewards, and suspension without pay (consequence).

On the other hand, social rewards included full appreciate of work done, personal loyalty to employees, interesting work, issues related to personal problems and verbal or other non-economic recognition. According to (Hedge et al. 2006) study on the aging workforce: Realities, myths, and implications for organizations discovered that employee preference varies based on their age category as employees get older they prefer more non- monetary rewards and skill rather than monetary rewards. Hence, this study suggests that providing non-monetary rewards for older age employees can motivate them better. Similarly, Nienaber et al. (2011) explained that non-monetary rewards are more preferred by younger employees than older employees. However, Cennamo \& Gardner (2008) study conducted on generational differences in work values, outcomes and person found that monetary rewards or extrinsic rewards are highly preferred by older employees than younger employees. Snelgar et al. (2013) empirical study conducted on the reward preferences of employees discovered that respondents in the age group 18-29 years (Generation Y) place less importance on base pay and contingency or variable pay than older respondents. On the other hand, Younger employees, place more value on rewards such as work-home integration.

Snelgar et al. ( 2013) indicates monetary rewards are considered to be the most important reward category by the employees and non- monetary rewards are rated as least important reward category. According to (Hsieh \& Chen, 2006) study on key trends of the total reward system in the 21 st century has shown that employees who perform at outstanding level work for beyond money or monetary rewards rather they are looking for non-monetary rewards for their job that can offer them an opportunity for professional and personal growth, recognition and autonomy.

Snelgar et al. ( 2013) have shown that gender and age were found to be related to reward preferences, but marital status and educations level have no relationship with the importance of rewards. In terms of gender, the results revealed that women prefer pay more than men and this implies that women place more importance on pay and favorable working environment.

Generally, the study concludes that both male and female employees were much concerned with economic or monetary rewards issues such as job security, good wages, and good working conditions. However, when discussing specific situational reward preferences, social rewards (like thank you from the boss) consistently and considerably ranked higher than monetary rewards. This indicated that employees valued rewards that do not incur an additional financial burden on the company. According to (Nienaber et al. 2011) study on the relationship between personality types and reward preferences has shown that reward preferences differ in terms of certain 
demographic factors - for example, age, educational qualifications, work experience, marital status and gender. The result of this study explained in detail as follow:

The study has discovered that statistically significant mean differences were present with respect to all age groups, in terms of both reward categories. For both type of reward categories, the respondents in the age group 18 years -38 years indicated the highest mean preference score and the mean preference score progressively lowered as the respondents got older.

The assumption can therefore be made that reward categories such as remuneration and benefits and a conducive working environment are much more important to the younger employees, and reduce in need as employees get older. As far as concerned preferences for the reward category remuneration and benefits, statistically there were significant mean differences among respondents with a matric qualification, respondents with a degree/diploma as their highest qualification and respondents with a postgraduate qualification. In all cases, the lower the level of educational qualification, the higher the mean preference score. Generally study confirms that respondent with lower level educational qualification rate monetary rewards more than respondent with higher educational qualification.

In terms of working experience or year of service the study has revealed that statistically significant mean differences were observed among respondents working experience or years of service. The longer employees are employed by an organization, the weaker their preference for a favorable working environment has been discovered. One would expect that employees who are new to the organization would feel less confident about their ability to acquainted with their working environment, or be accepted by their new teams; colleagues and their line manager compared to employees who have much longer service and hence they would report a stronger preference. Finally, this study also has discovered that there was statistically significant mean preference difference between men and women with respect to both reward categories. The mean scores were found to be significantly higher for women than for men. Therefore, Women have a stronger preference for monetary rewards such as remuneration and benefits.

\subsection{Controversies over monetary and non-monetary rewards in relation with motivation.}

Throughout the existence of scientific management monetary rewards were considered as the single and most important motivator for employees. In contrast, the human relations movement which came out in the 1920s changed the scientific management simplistic view on motivation of employees by demonstrating that employees are also motivated through social needs such as having a good relationship with social group next to pure monetary rewards such as money. This fresh view led to the human resources movement which adopted a differentiated approach towards rewards.

Rewards not only include money but also affiliation, success and executing challenging and meaningful job (Elding, Tobias \& Walker 2006 cited by Pepermans, 2012). Bussin (2002) recommended that it is not necessarily only cash or a gift that will provide a long lasting impression on the hard worker, the appreciation of their coworker and colleagues also play a great role. The following unofficial ways can be also used to recognize individual and team success. Such as a verbal "thank you" or "well done", a thank you card, a letter of recognition on the achiever's personal file a congratulations card and so on. He further explained that the disadvantages of monetary rewards are they have no trophy value (cited by the same author).

The motivation of employees and their productivity can be improved through delivering them effective recognition which eventually leads to improved performance of organizations. The complete success of an organization is based on the way how an organization retains its employees motivated and in what way they evaluate the performance of employees for job compensation. Occasionally, management pays higher attention to extrinsic rewards however intrinsic rewards are equally essential in employees' motivation. Intangible or psychological rewards like appreciation and recognition play a vital role in motivating employee employees and increasing their productivity (Hafiza et al. 2011). Nazir et al.( 2012) also suggest that using the non monetary rewards as component of total rewards is important because it is a powerful tool to initiate employees to put forth extra effort through acknowledging employees' achievement and commitment.

Lameck (2011) study on non-financial motivation as strategy for improving performance police force in Tanzania also proved that non-monetary rewards are valued highly by the employees and he argued that nonmonetary rewards are effective in motivating public employees and vital to satisfy employees many other needs such as social interaction, belongingness, recognition, respect, attention, a feeling of achievement, autonomy, a meaningful job, a feeling of self-worth, developing one's full potential, feedback about performance etc. in addition to this, it is a valuable means of recognizing any contribution made, suggestion and success of the employees. Therefore, the findings of this study conclude that non-monetary incentives/rewards have strong potential on motivating public employees. However, Study conducted on the association between reward and employee motivation at the banking Sector of Pakistan shows that financial reward ranked first as motivational factors. Thus, monetary rewards are most preferable by the employees than monetary rewards. From this it is possible to infer that rewarding employees with money motivate them better to accomplish their organization goals 
than employees who awarded or provided non-monetary rewards (Muhammad et al. 2011).

Effort also made to determine the association between factors that motivate the public employees. According to the findings obtained from this study managers are more motivated by non- monetary rewards than monetary rewards and employees are more motivated by financial rewards than non-financial rewards ( Öztürk and Dündar 2003 cited Erbaş \& Arat, 2012).

But, empirical findings of Taljaard (2003) has shown even if employees respond that monetary rewards such as salary and wages, annual company performance bonuses and monthly target based incentive schemes important for good performance, they don't believe that don't believe that it is the only and the most effective rewards that could motivates them for excellent performance . They said that money is a short-term motivator for them and it has not long lasting effects on employee motivation. Generally, the findings of this study concluded that non-monetary rewards have the most motivating effects on employees for great performance better than monetary rewards. Although pay is one of the most influential factors when it comes to attracting, motivating and retaining employees, organizations should not only use this as component of rewards to attract, motivate and retain employees but non-financial elements also should be incorporated as components of total rewards package (Tande \& Hill, 2006). However, study conducted on industrial employees' shows that non-monetary rewards like appreciation and recognition of the work done is found to be the most preferred motivational factor. Hence, this study concludes that the motivational powers of non-monetary rewards are greater than monetary rewards (Kovach 1980 cited by Lameck, 2011). In opposition, Armstrong (2007, pp: 330) wrote money is a powerful motivating force because it is linked directly or indirectly to the satisfaction of many needs. Money by itself has no intrinsic meaning, but it acquires significant motivating power because it comes to represent so many intangible goals. In line with what is explained above, Frederick Taylor and his scientific management associate also described money as the most fundamental factor in motivating the workers to attain greater productivity.

In contradiction to what is stated above, Manzoor (2012) argued that recognition and empowerment (nonmonetary rewards) play a great role in enhancing employee motivation towards accomplishment organizational objective through appreciating the employees for their work done and allow them to involve in decision making practices.

Nujjoo \& Meyer ( 2012)Study on investigate how favorable perceptions of rewards are related to intrinsic motivation and affective commitment also revealed that it is essential for organizations to emphasize the on value of intrinsic rewards as component of their rewards management strategies. By effectively managing their rewards strategies organizations can attract retain and capitalize on the benefits of a loyal and high caliber workforce. Metaanalyses of research on motivation shown that even if so far, managers view monetary rewards as the prime motivator of employees, people never rate money as their major motivator. Money is a factor that attracts people but does not play an essential role in keeping and motivating them and the largest workforce in the world is made up of volunteer workers who do not do the work to earn money Arnolds \& Venter (2007). Likewise, (Rynes et al. 2004) conducted their study on the importance of pay in employee motivation and their findings confirmed that money is not the sole and primary motivator for everyone. Similarly, according to Rashid (2012) monetary rewards such as bonuses, performance based payment would not be powerful tools on the motivation and retention of public sector workers than private sector employees. Rewards and benefits that people receive from their organization are anticipated to vary between public and private sector organizations.

On the other hand, Kirstein (2010) argued that monetary reward is still the most critical motivating factor for employees that makes them perform higher in the in the organization and also argued that intrinsic rewards motivate people but after a particular point of time money become the leading motivators. According to (Gupta \& Mitra, 1998) Study's on the value of financial incentives proved that money is an important employee's motivator. Similarly, (Danish \& Usman, 2010)study on impact of reward and recognition on job satisfaction and motivation indicated that although many dimensions of work and job motivation are related to motivation and satisfaction but recognition, work itself and operating procedures have many low mean values as compared to other dimensions. This shows that employees are less motivated with their work contents, difficulties of operating procedures and neglecting the aspects of recognition. On the other hand, when the employees have sufficient promotional opportunities their relationship with co- workers are friendly, they are paid for what they work, and they find their job secured, their supervisors are cooperative and they feel that they can grow living within the organizations, then their level of motivation is very high. Generally, this study concluded that employees are highly motivated with monetary rewards.

However, kluvers and Tippet (2009) opposing the above view and confirmed that intrinsic or non-monetary rewards motivational factors have been found to be vital in employee motivation, in both the presence and absence of an employee bonus system. Monetary reward motivates employees but not equal as much as non-monetary reward does. The introduction of a bonus had very little effects on motivation. Professors Adam Grant and Jitendra Singh also argued that it is time to cut back money as a chief motivational force in business. Instead, they emphasized organizations should pay greater attention to Non-financial rewards rather than the financial one. Meaning that designing jobs that provide opportunities to make choices, develop skills, do work that matters and 
build meaningful interpersonal connections have impact on employees’ motivation (Knowledge@Wharton, 2011).

Supporting the above view, a survey of research findings on work motivation has suggested that nonmonetary rewards are ranked as better motivational tool as compared to monetary rewards. Aworemi et al. (2011) discovered non-monetary rewards hold the attention of employees. Providing non-monetary rewards captures the mind of an employee's better than what monetary rewards do. Then it makes them to think more about it regularly and it result in employee motivation. The study recommends that using pay as motivational tool may not be the most effective in motivation. According to Qureshi et al.(2010) financial rewards are not the most motivating factor and have de-motivating effect on employees. But, Hafiza et al. (2011) have found that non-monetary rewards have a weaker influence on employee motivation. They also found that indirect relationship has been found between appreciation and employee motivation as employees of the organizations are not satisfied with their pay packages. Therefore, in the absence of extrinsic rewards which is the basic source of motivation for employee, intrinsic rewards like recognition, appreciation and empowerment is of little importance. Pay is potentially powerful tool to employee motivation so the employees can only be intrinsically motivated to perform an activity when they are fully satisfied with the pay they are getting.

\subsection{Conceptual framework}

Under this study employees' motivation is taken as dependent variable while demographic characteristics and monetary and non-monetary rewards are taken as independent variables. However, there a situation in which rewards could be dependent variables. For instance, in case of question that investigates employees' rewards preference based on their demographic characteristics; rewards could be taken as dependent variables while demographic characteristics taken as independent variable. Whereas, for research question which emphasis on identifying significant difference among employees' reward preference in relation with motivation generally not particularly depends on their demographic characteristics, reward could be taken as independent variable and but motivation is taken as dependent variable because employees motivation is dependent up on a type of reward employees prefer. Generally, dependent as well as independent variable were measured by the feedback from employees taken through self-designed closed ended questionnaire.

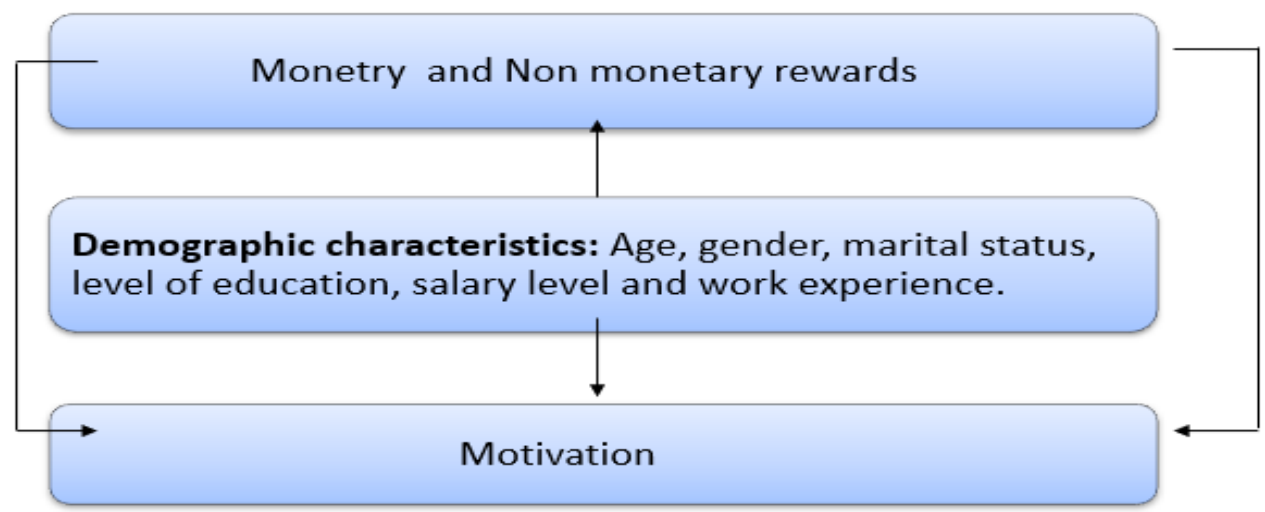

Fig.1 Conceptual framework, source: The researcher

\section{METHODOLOGY}

\subsection{Research Design}

The study used descriptive research design. The objectives of descriptive research is describing present conditions, studying immediate status of a phenomenon, finding facts and examining the relationships of traits and characteristics (Singh, 2006 p.105).

\subsection{Population and Sample frame}

The total population of the study was about about157 employees. The sample of frame of the study encompasses only non-managerial employees of the organization those were about 150 and the rest 7 employees were found to be managers and excluded from the investigation because they were beyond study's scope.

\subsection{Sampling method and Sample size}

The researcher draws sample from 150 employees using simple random sampling which is known as probability sampling technique. The study draws 110 respondents as a sample by using (Cochran's, 1977) formula as indicated on (Barttlett, Kotrlik, \& Higgins, 2001).

$$
n=\frac{N}{1+N(e)^{2}}
$$


Where: $\mathrm{n}=$ denotes the number of sample used; $\mathrm{N}=$ designates total number of employees; $\mathrm{e}=$ designates margin of error $5 \%(.05) \mathrm{l}=$ denotes the probability of the event occurring. Therefore, total 110 respondents were selected to include in the study.

\subsection{Data sources and types}

This study used only primary data. The source of this primary data was 5 points Likret scale type questionnaire.

\subsection{Data Collection Instruments}

Likret scale type structured questionnaire was developed as data collection instrument to collect relevant and reliable information from the respondent's to answer the basic question raised.

\subsection{Method of Data Analysis}

The collected data was analyzed using Statistical Package for Social Sciences (SPSS). The analysis part consists of descriptive statistics (frequency and cross tabs). In order to test the strength of the relationship between each predictor (independent variable) and dependent variable as well as variance among the variables, the analysis was subjected to T-test and Chi-square test. Lastly, the analyzed data were presented in the form of tables and graphs.

\section{Data analysis and Outcomes}

This part of the study presents about the completion and return rate of the instruments developed by the researcher. As the study encompasses different participants like administrative and clerical's workers, technical and skilled expertise, and custodian at Ethio Telecom Adama branch, proper attention were given for the right completion and return back of the questionnaire. Accordingly, the selected research participants fill the survey questionnaire distributed to them very nicely with return rate of more than $78 \%$.

Table 1: Socio-Demographic Profile of Survey participants

\begin{tabular}{|c|c|c|c|c|}
\hline \multicolumn{2}{|c|}{ Socio-Demographic Variables } & Frequency & Percent & Cumulative Percent \\
\hline sex & $\begin{array}{l}\text { Male } \\
\text { Female } \\
\text { Total } \\
\end{array}$ & $\begin{array}{l}55 \\
31 \\
86 \\
\end{array}$ & $\begin{array}{l}64.0 \\
36.0 \\
100.0 \\
\end{array}$ & $\begin{array}{l}64.0 \\
100.0\end{array}$ \\
\hline $\begin{array}{l}\text { Age } \\
\text { categorized }\end{array}$ & $\begin{array}{l}18-25 \\
26-35 \\
36-45 \\
>=46 \\
\text { Total }\end{array}$ & $\begin{array}{l}6 \\
44 \\
26 \\
10 \\
86\end{array}$ & $\begin{array}{l}7.0 \\
51.2 \\
30.2 \\
11.6 \\
100.0\end{array}$ & $\begin{array}{l}7.0 \\
58.2 \\
88.4 \\
100.0\end{array}$ \\
\hline Marital status & $\begin{array}{l}\text { Single } \\
\text { Married } \\
\text { Divorced } \\
\text { Total }\end{array}$ & \begin{tabular}{|l|}
24 \\
48 \\
14 \\
86 \\
\end{tabular} & $\begin{array}{l}27.9 \\
55.8 \\
16.3 \\
100.0\end{array}$ & $\begin{array}{l}27.9 \\
83.7 \\
100.0\end{array}$ \\
\hline $\begin{array}{l}\text { Educational } \\
\text { Status }\end{array}$ & $\begin{array}{l}\text { Certificate } \\
\text { Diploma } \\
\text { 1st Degree } \\
\text { MA/2nd Degree } \\
\text { Total }\end{array}$ & $\begin{array}{l}1 \\
18 \\
54 \\
13 \\
86\end{array}$ & $\begin{array}{l}1.2 \\
20.9 \\
62.8 \\
15.1 \\
100.0\end{array}$ & $\begin{array}{l}1.2 \\
22.1 \\
84.9 \\
100.0\end{array}$ \\
\hline $\begin{array}{l}\text { Experience in } \\
\text { Ethio Telecom }\end{array}$ & $\begin{array}{l}<=5 \text { years } \\
6-10 \text { years } \\
11-15 \text { years } \\
>=16 \text { years } \\
\text { Total }\end{array}$ & $\begin{array}{l}24 \\
24 \\
14 \\
24 \\
86\end{array}$ & $\begin{array}{l}27.9 \\
27.9 \\
16.3 \\
27.9 \\
100.0\end{array}$ & $\begin{array}{l}27.9 \\
55.8 \\
72.1 \\
100.0\end{array}$ \\
\hline salary level & $\begin{array}{l}920-2400 \\
2401-3680 \\
3681-7500 \\
\text { Above } 7500 \\
\text { Total }\end{array}$ & $\begin{array}{l}32 \\
26 \\
14 \\
14 \\
86\end{array}$ & $\begin{array}{l}37.2 \\
30.2 \\
16.3 \\
16.3 \\
100.0\end{array}$ & $\begin{array}{l}37.2 \\
67.4 \\
83.7 \\
100.0\end{array}$ \\
\hline
\end{tabular}

Source: survey Data 
6.1 Preference of employees towards monetary and non-monetary rewards

6.1.1 Comparison of employees' reward preference

Table 2: Descriptive statistics

\begin{tabular}{|l|l|l|l|l|}
\hline Preferences & $\mathrm{N}$ & Mean & Std. Deviation & Std. Error Mean \\
\hline Monetary preferences & 86 & .8216 & .14566 & .01571 \\
\hline Non-monetary preferences & 85 & .8135 & .15733 & .01707 \\
\hline
\end{tabular}

Source: own computation

In this regard, the descriptive statistics mentioned in table 2 show, employees' monetary preferences have value of $0.822 \pm 0.146$ mean and standard deviations. Whereas, the nonmonetary employees' preferences have mean value of $0.813 \pm 0.157$ Standard deviations. These analyses refer the mean value of employees' monetary preferences are a little bit greater than the nonmonetary employees' preferences.

Table 3: One-Sample Statistics

\begin{tabular}{|c|c|c|c|c|c|c|}
\hline \multirow{3}{*}{ Preferences } & \multicolumn{6}{|c|}{ Test Value } \\
\hline & \multirow[b]{2}{*}{$\mathrm{T}$} & \multirow[b]{2}{*}{ Df } & \multirow[b]{2}{*}{ Sig. (2-tailed) } & \multirow[b]{2}{*}{ Mean } & \multicolumn{2}{|c|}{$95 \%$ Confidence Interval of the difference } \\
\hline & & & & & Lower & Upper \\
\hline Monetary preferences & 52.305 & 85 & .000 & .82158 & .7903 & .8528 \\
\hline Non-monetary preferences & 47.668 & 85 & .000 & .81345 & .7795 & .8474 \\
\hline
\end{tabular}

Source: own computation

Moreover in table 3 above, show the one sample t statistics; according to this test statistics the lower and upper limit for both employees preferences were $.7903, .8528$ and $.7795, .8474$ respectively. Meaning, the lower and upper limit for employees' monetary preferences are greater than Nonmonetary preferences at $t$ value of 52.305 $(\mathrm{p}=0.000)$ and $46.668(\mathrm{p}=0.000)$ respectively.

Table 4: Paired t test statistics

\begin{tabular}{|c|c|c|c|c|c|c|c|c|c|}
\hline \multirow{3}{*}{ Preferences } & \multicolumn{5}{|c|}{ Paired Differences } & \multirow[b]{3}{*}{$\mathrm{t}$} & \multirow[b]{3}{*}{$\mathrm{df}$} & \multirow{3}{*}{$\begin{array}{l}\text { Sig. (2- } \\
\text { tailed) }\end{array}$} & \multirow{4}{*}{$\begin{array}{l}\text { Correlation } \\
.196\end{array}$} \\
\hline & \multirow[b]{2}{*}{ Mean } & \multirow{2}{*}{$\begin{array}{l}\text { Std. } \\
\text { Deviation }\end{array}$} & \multirow{2}{*}{$\begin{array}{l}\text { Std. } \\
\text { Error } \\
\text { Mean }\end{array}$} & \multicolumn{2}{|c|}{\begin{tabular}{|l}
$95 \%$ Confidence \\
Interval of the \\
Difference \\
\end{tabular}} & & & & \\
\hline & & & & Upper & Lower & & & & \\
\hline $\begin{array}{l}\text { Monetary } \\
\text { preferences \& Non- } \\
\text { monetary } \\
\text { preferences }\end{array}$ & .0102 & .19201 & .02083 & -.031 & .0516 & .490 & 84 & .626 & \\
\hline
\end{tabular}

Source: own computation

As depicted in table 4, the researcher run paired t test statistics to check whether there are any significant differences in employees' preference towards monetary and non-monetary rewards. Accordingly, the paired sample correlations result confirms the presence very weak associations between the two employees' preferences at correlation coefficient of .196. Moreover, the t-test statistics also show the absence of statistically significant difference in employees' reward preferences in Ethio Telecom Adama branch at t value of $.490(\mathrm{P}=.626)$. Because it is out of the acceptable confidence level $(95 \%)$ and tolerable error level $(0.05)$. See table 4 for the details.

\subsection{Employees preferences by demographic characteristics}

\subsubsection{Table 5: Employees preferences by Gender}

\begin{tabular}{|c|c|c|c|c|c|c|c|c|c|c|c|}
\hline \multirow[b]{4}{*}{ Sex } & \multirow[b]{4}{*}{ frequency } & \multicolumn{5}{|c|}{ Monetary Preferences } & \multicolumn{5}{|c|}{ Non-monetary Preferences } \\
\hline & & \multirow{3}{*}{$\begin{array}{l}\text { not } \\
\text { confirmed }\end{array}$} & \multirow[b]{3}{*}{ confirmed } & \multirow[b]{3}{*}{ Total } & \multicolumn{2}{|c|}{$\begin{array}{l}\text { chi-square } \\
\text { test }\end{array}$} & \multirow{3}{*}{$\begin{array}{l}\text { not } \\
\text { confirmed }\end{array}$} & \multirow[b]{3}{*}{ confirmed } & \multirow[b]{3}{*}{ total } & \multicolumn{2}{|c|}{$\begin{array}{l}\text { chi-square } \\
\text { test }\end{array}$} \\
\hline & & & & & value & sig. & & & & value & sig. \\
\hline & & & & & \multirow{7}{*}{.637} & \multirow{7}{*}{.544} & & & & & \\
\hline \multirow[t]{2}{*}{ Male } & Count & 3 & 52 & 55 & & & 4 & 51 & 55 & \multirow{6}{*}{.917} & \multirow{6}{*}{644} \\
\hline & $\%$ & $3.5 \%$ & $60.5 \%$ & $64.0 \%$ & & & $4.7 \%$ & $60.0 \%$ & $64.7 \%$ & & \\
\hline \multirow[t]{2}{*}{ Female } & Count & 1 & 30 & 31 & & & 2 & 28 & 30 & & \\
\hline & $\%$ & $1.2 \%$ & $34.9 \%$ & $36.0 \%$ & & & $2.4 \%$ & $32.9 \%$ & $35.3 \%$ & & \\
\hline \multirow[t]{2}{*}{ Total } & Count & 4 & 82 & 86 & & & 6 & 79 & 85 & & \\
\hline & $\% 0$ & $4.7 \%$ & $95.3 \%$ & $100 \%$ & & & $7.1 \%$ & $92.9 \%$ & $100 \%$ & & \\
\hline
\end{tabular}

Source: own computation

According to the above chi-square test, the result confirms that the absence of significant difference in 
employees' preferences of rewards in relation with Gender difference at p (.544) and P (.644) monetary and nonmonetary preferences respectively.

6.2.2 Employees preferences by Age

Table 6: Paired Samples Statistics

\begin{tabular}{|c|c|c|c|c|c|c|c|c|}
\hline & & Mean & $\mathrm{N}$ & $\begin{array}{l}\text { Std. } \\
\text { Deviation }\end{array}$ & $\begin{array}{l}\text { Std. Error } \\
\text { Mean }\end{array}$ & correlation & value & sig. \\
\hline Pair & Age \& Monetary & 35.23 & 86 & 7.115 & .767 & -.045 & 44.799 & .684 \\
\hline 1 & preferences & .8216 & 86 & .14566 & .01571 & & & \\
\hline $\begin{array}{l}\text { Pair } \\
2\end{array}$ & $\begin{array}{l}\text { Age \& } \\
\text { Non-monetary preferences }\end{array}$ & 35.23 & 86 & 7.115 & .767 & .318 & 45.173 & .003 \\
\hline
\end{tabular}

The above paired t test result confirms the presence of negative associations between respondents' ages and monetary reward preferences. Meaning, in this analysis as age of the respondents' increases employees' preferences for the monetary rewards decreases though it is not statistically significant $p(.684)$. Whereas, the nonmonetary employees reward preference increases positively as age of the employees increases and also shown the presence of statistically significant difference among the employees' preferences at probability level of $\mathrm{p}(.003)$.

\subsubsection{Table 6: Employees preferences by marital status}

\begin{tabular}{|c|c|c|c|c|c|c|c|c|c|c|c|}
\hline \multirow[t]{2}{*}{$\begin{array}{l}\text { Marital } \\
\text { status }\end{array}$} & & \multicolumn{2}{|c|}{ Monetary preferences } & \multirow[t]{2}{*}{ Total } & \multirow{2}{*}{$\begin{array}{l}\text { chi- } \\
\text { Square } \\
\text { value }\end{array}$} & \multirow[b]{2}{*}{ Sig. } & \multicolumn{2}{|c|}{$\begin{array}{l}\text { Nonmonetary } \\
\text { Preferences }\end{array}$} & \multirow[t]{2}{*}{ Total } & \multicolumn{2}{|c|}{ Chi square } \\
\hline & & $\begin{array}{l}\text { not } \\
\text { confirmed }\end{array}$ & confirmed & & & & $\begin{array}{l}\text { not } \\
\text { confirmed }\end{array}$ & confirmed & & value & sig. \\
\hline \multirow[t]{2}{*}{ Single } & Count & 2 & 22 & 24 & \multirow[t]{8}{*}{1.643} & \multirow[t]{8}{*}{.440} & 2 & 22 & 24 & \multirow[t]{8}{*}{1.254} & \multirow[t]{8}{*}{.534} \\
\hline & $\%$ & $2.3 \%$ & $25.6 \%$ & $27.9 \%$ & & & $2.3 \%$ & $25.6 \%$ & $27.9 \%$ & & \\
\hline \multirow[t]{2}{*}{ Married } & Count & 1 & 47 & 48 & & & 4 & 44 & 48 & & \\
\hline & $\%$ & $1.2 \%$ & $54.7 \%$ & $55.8 \%$ & & & $4.7 \%$ & $51.2 \%$ & $55.8 \%$ & & \\
\hline \multirow[t]{2}{*}{ Divorced } & Count & 1 & 13 & 14 & & & 0 & 14 & 14 & & \\
\hline & $\%$ & $1.2 \%$ & $15.1 \%$ & $16.3 \%$ & & & $.0 \%$ & $16.3 \%$ & $16.3 \%$ & & \\
\hline \multirow[t]{2}{*}{ Total } & Count & 4 & 82 & 86 & & & 6 & 80 & 86 & & \\
\hline & $\%$ & $4.7 \%$ & $95.3 \%$ & $100.0 \%$ & & & $7.0 \%$ & $93.0 \%$ & $100.0 \%$ & & \\
\hline
\end{tabular}

Source: own computation

In the above table, when compared the presence of significant difference among the employees' preferences by their marital status; the statistical analysis has shown the absence of difference in employees' monetary and nonmonetary preference as a reward in the sated branch. This confirmed by very low chi square test value of 1.643 and 1.254 at probability level of $\mathrm{P}(.440)$ and $\mathrm{P}(.534)$ for both monetary and non-monetary employees' preferences respectively. Meaning the lesser the chi square value indicates the more error presence (subject to be out of the tolerable error of 0.05) in explaining respondents' marital status.

\subsubsection{Employees preferences by educational status}

\begin{tabular}{|l|l|l|l|l|l|l|}
\hline \multirow{2}{*}{ Education } & Frequency & Monetary preferences & Total & \multicolumn{2}{l|}{ chi square } \\
\cline { 2 - 7 } & & Not confirmed & confirmed & & Value & sig. \\
\hline Certificate & Count & 0 & 1 & 1 & .462 & .927 \\
\hline & $\%$ & $.0 \%$ & $1.2 \%$ & $1.2 \%$ & & \\
\hline Diploma & Count & 1 & 17 & 18 & & \\
\hline & $\%$ & $1.2 \%$ & $19.8 \%$ & $20.9 \%$ & & \\
\hline st Degree & Count & 2 & 52 & 54 & & \\
\hline $\begin{array}{l}\text { MA/2nd } \\
\text { Degree }\end{array}$ & $\%$ & $2.3 \%$ & $60.5 \%$ & $62.8 \%$ & & \\
\hline & Count & 1 & 12 & 13 & & \\
\hline Total & $\%$ & $1.2 \%$ & $14.0 \%$ & $15.1 \%$ & & \\
\hline & Count & 4 & 82 & 86 & & \\
\hline
\end{tabular}

The conclusion made from the above table is that no statistically significant association between education status and monetary preferences of the respondents. 
6.2.5 Table7: Employees' monetary preferences by their education level

\begin{tabular}{|l|l|l|l|l|l|l|}
\hline \multirow{2}{*}{ Education } & Frequency & Monetary preferences & Total & \multicolumn{2}{l|}{ chi square } \\
\cline { 2 - 7 } & & Not confirmed & confirmed & & Value & sig. \\
\hline Certificate & Count & 0 & 1 & 1 & .462 & .927 \\
\hline & $\%$ & $.0 \%$ & $1.2 \%$ & $1.2 \%$ & & \\
\hline Diploma & Count & 1 & 17 & 18 & & \\
\hline & $\%$ & $1.2 \%$ & $19.8 \%$ & $20.9 \%$ & & \\
\hline 1st Degree & Count & 2 & 52 & 54 & & \\
\hline & $\%$ & $2.3 \%$ & $60.5 \%$ & $62.8 \%$ & & \\
\hline $\begin{array}{l}\text { MA/2nd } \\
\text { Degree }\end{array}$ & Count & 1 & 12 & 13 & & \\
\hline & $\%$ & $1.2 \%$ & $14.0 \%$ & $15.1 \%$ & & \\
\hline Total & Count & 4 & 82 & 86 & & \\
\hline & $\%$ & $4.7 \%$ & $95.3 \%$ & $100.0 \%$ & & \\
\hline
\end{tabular}

Source: own computation

Here, the statistical analysis of the chi square test result show, the absence of significant difference among the employees' preferences by their educational level at value of .462 and probability level of .927.

6.2.6 Non-monetary preferences by employees' educational status

Table 8

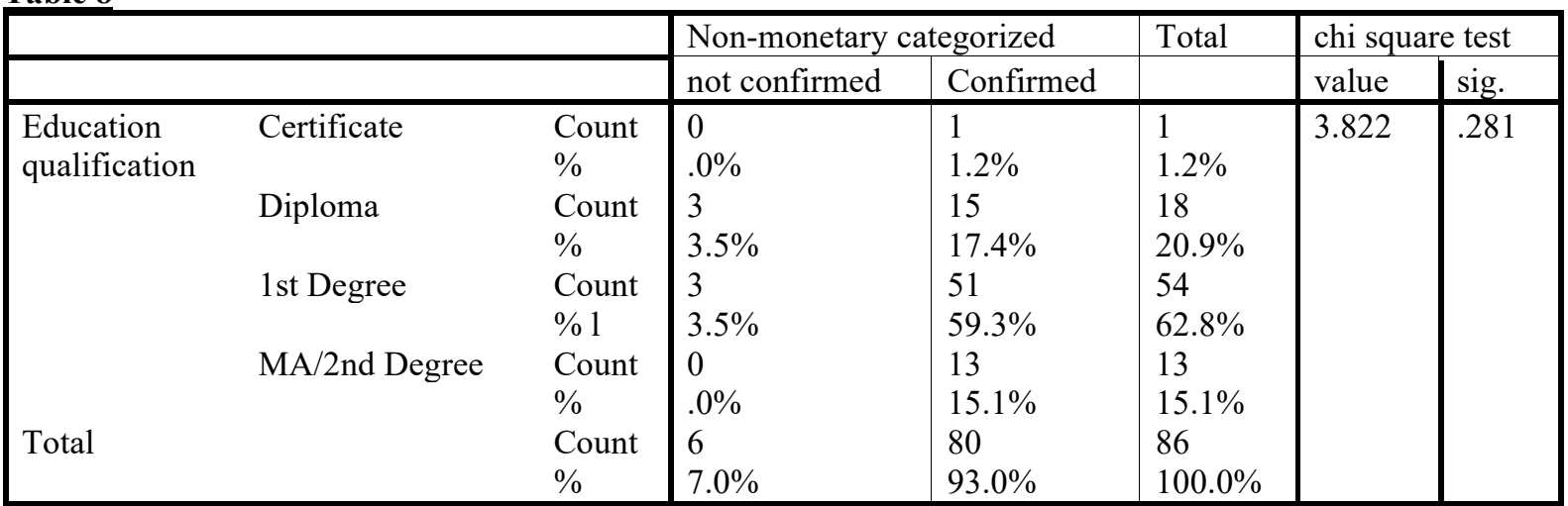

Source: own computation

In this case, also like the above monetary preference analysis, the chi square test result show the absence of statistically significant difference among the employees' nonmonetary preference by their educational status. In general, comparatively speaking no difference response was seen among the employees monetary and nonmonetary preference by their educational level.

\subsubsection{Employees preferences by Experience}

\section{Table 9: Paired Samples Statistics}

\begin{tabular}{|ll|l|l|l|l|}
\hline & & & & Std. Error \\
& & Mean & N & Std. Deviation & Mean \\
\hline Pair 1 & Experience \& & 11.48 & 86 & 8.276 & .892 \\
& Monetary preferences & .8216 & 86 & .14566 & .01571 \\
Pair 2 & experience \& & 11.48 & 86 & 8.276 & .892 \\
& Non-monetary preferences & .8119 & 86 & .15706 & .01694 \\
\hline
\end{tabular}

Source: own computation

Table 9 above show the average experience year in Ethio Telecom in Adama Branch is 11.48 years with the standard deviations of 8.276. This shown there are a large difference in employees' experience year in the organization.

Table 10: Paired Samples Correlations

\begin{tabular}{|c|c|c|c|c|}
\hline & & $\mathrm{N}$ & Correlation & Sig. \\
\hline Pair 1 & Experience \& Monetary preferences & 86 & .049 & .657 \\
\hline Pair 2 & $\begin{array}{l}\text { Experience } \\
\text { preferences }\end{array}$ & 86 & .285 & .008 \\
\hline
\end{tabular}

Source: own computation

The above table displays the association between monetary and nonmonetary employees' preference have positive correlation value with experience of the employees. Which indicates in both cases, as experience of the employees' increases the need for monetary and non-monetary rewards also increases. Especially, the relation is 
very significant at probability level of 0.008 among the experience and nonmonetary preferences.

6.2.8 Employee preferences by Salary

Table 11: Monetary preferences by salary of the employees

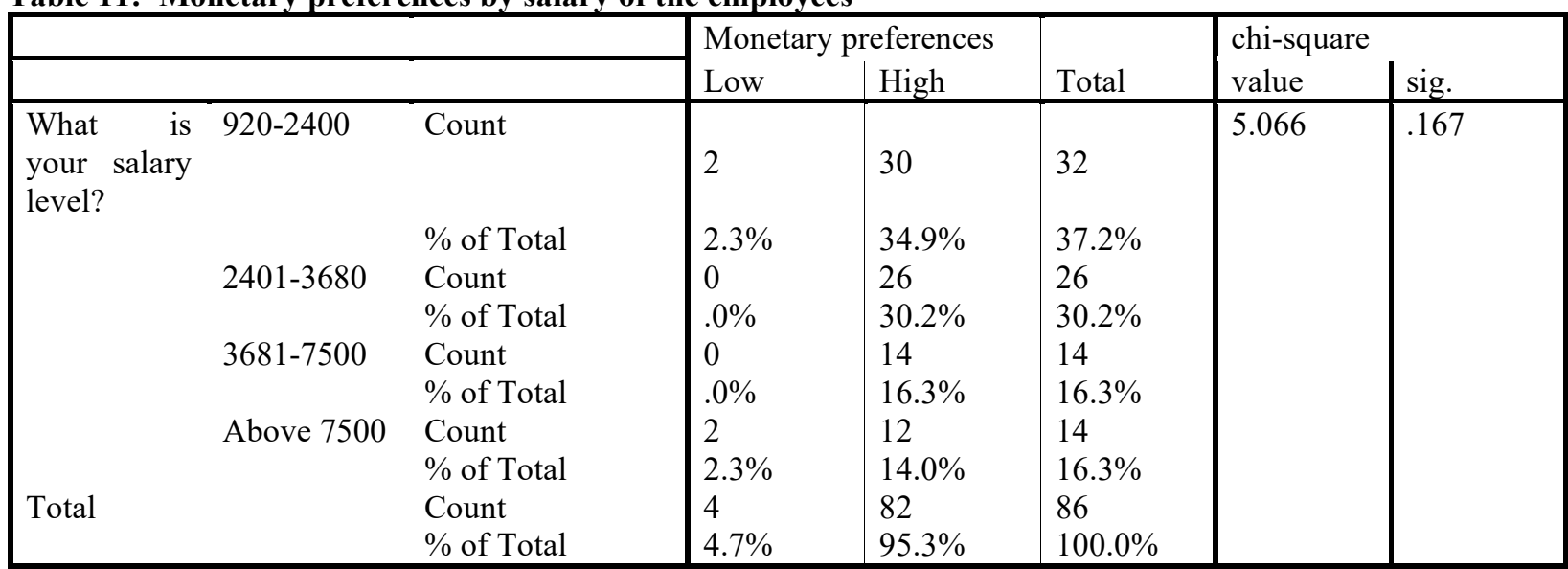

Source: own computation

The table above revels no statistically significant difference among the employees at P (.167), because of the majority of the respondents' falls in one category.

Table 12: Non-monetary preferences by salary of the employees

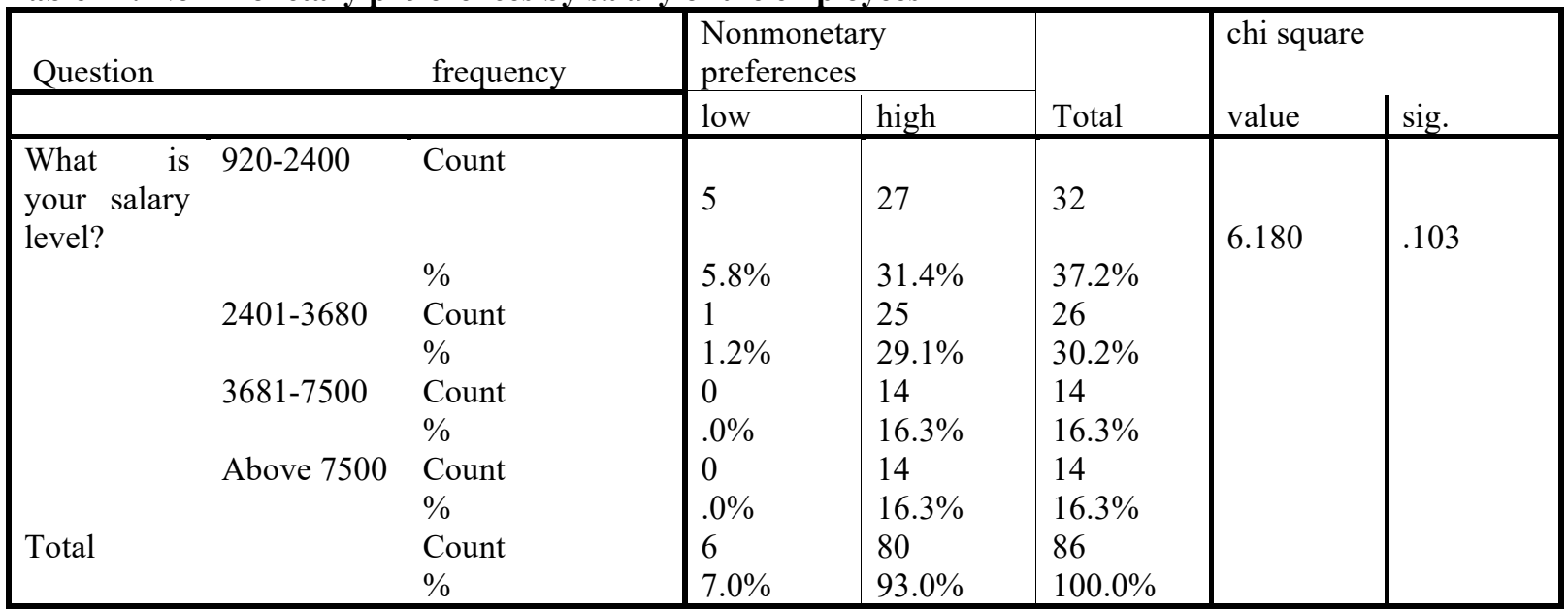

As per table 12 results, still in non-monetary analysis the chi square test result not confirmed the presence of significance difference among the employees. 


\subsection{Employees motivation level by demographic characteristics}

6.3.1 Descriptive statistics of employees' motivation level

Table 13: Descriptive statistics

\begin{tabular}{|ll|l|}
\hline N & Valid & 86 \\
Mean & Missing & 0 \\
Median & & .7339 \\
Mode & & .7588 \\
Std. Deviation & & .80 \\
Skewness & & .16073 \\
Std. Error of Skewness & & -.577 \\
Kurtosis & & .260 \\
Std. Error of Kurtosis & & 1.283 \\
Range & 25 & .514 \\
Minimum & & .95 \\
Maximum & 50 & .20 \\
Percentiles & & 1 \\
& 75 & .6206 \\
& & .7588 \\
\end{tabular}

Table 13 above show, the overall descriptive statistics of employees motivation level by comparing with normal distribution; hence as the center of the employees motivation level distribution can be approximated by the median or second quartile has value of .7539 , and half of the data values fall between .6206 and .7588, the first and third quartiles. Also, the most extreme values are .20 and 1, the minimum and maximum respectively. Moreover, the analysis shown the mean is quite different from the median i.e., .7339 though the distribution is symmetric (normal). This suspicion is confirmed by the negative skewness-.577 which shows that employees' motivation level has a long right tail with some distant values in a negative direction from the center of the distribution. Moreover, the standard deviation is .16073; hence low variation in results of employees' motivation level.

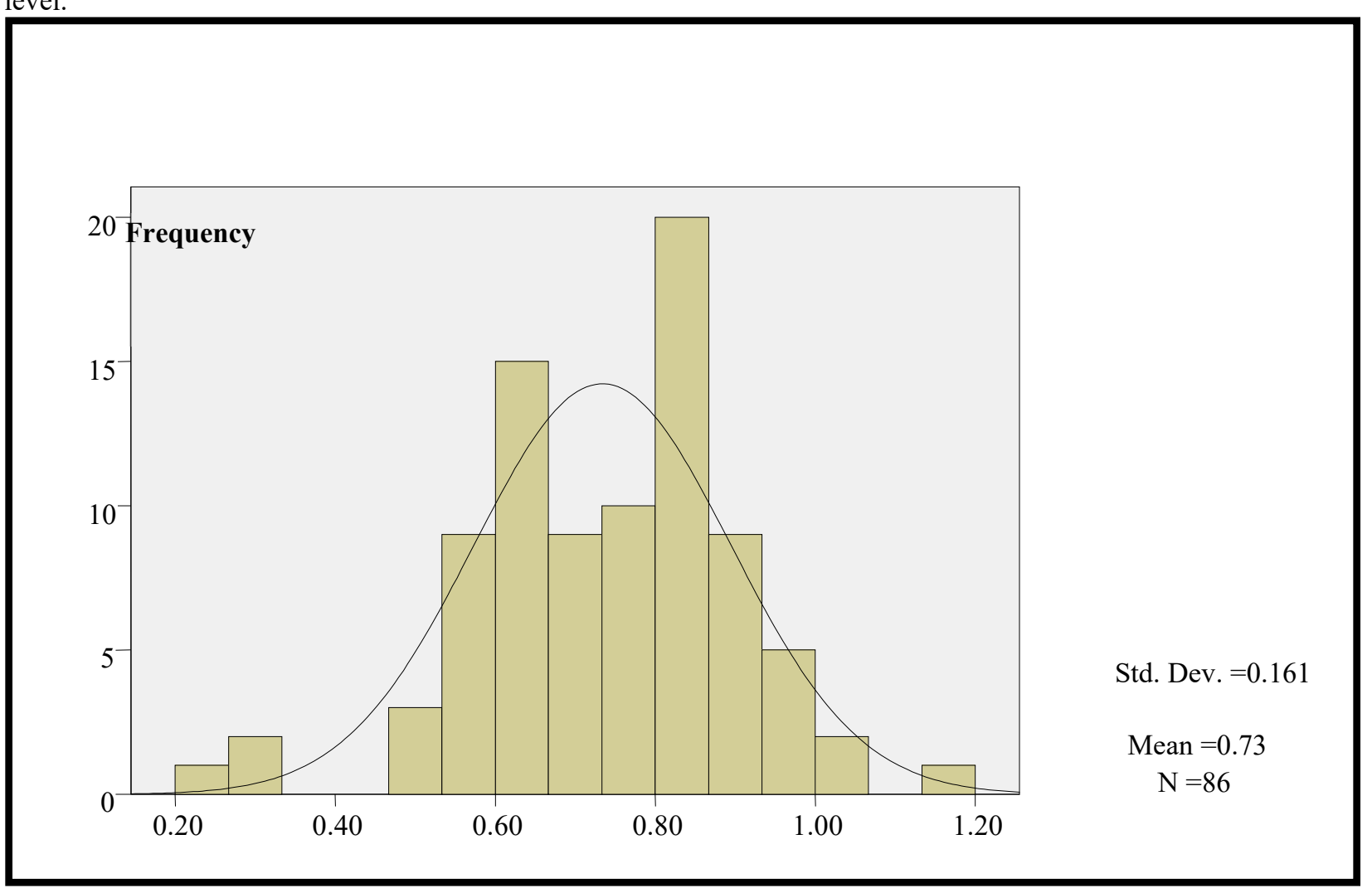

Fig.3: Distribution of motivation level 
Table 14: Motivation level by sex of the Employees

\begin{tabular}{|c|c|c|c|c|c|c|}
\hline \multirow[b]{2}{*}{ Sex } & \multirow[b]{2}{*}{ Frequency } & \multicolumn{2}{|c|}{ Motivation level } & \multirow[b]{2}{*}{ Total } & \multicolumn{2}{|c|}{ chi square } \\
\hline & & low & High & & value & sig. \\
\hline \multirow[t]{2}{*}{ Male } & Count & 2 & 53 & 55 & \multirow[t]{6}{*}{.921} & \multirow[t]{6}{*}{.706} \\
\hline & $\%$ & $2.3 \%$ & $61.6 \%$ & $64.0 \%$ & & \\
\hline \multirow[t]{2}{*}{ Female } & Count & 1 & 30 & 31 & & \\
\hline & $\%$ & $1.2 \%$ & $34.9 \%$ & $36.0 \%$ & & \\
\hline \multirow[t]{2}{*}{ Total } & Count & 3 & 83 & 86 & & \\
\hline & $\%$ & $3.5 \%$ & $96.5 \%$ & $100.0 \%$ & & \\
\hline
\end{tabular}

Source: own computation

Concerning employees' motivation level by their sex, table 14 shows, statistical analysis of employees' motivation level by sex of the employees does not indicates the presence of statistically significant difference at probability level of .706 (see table 14 and fig. 4).
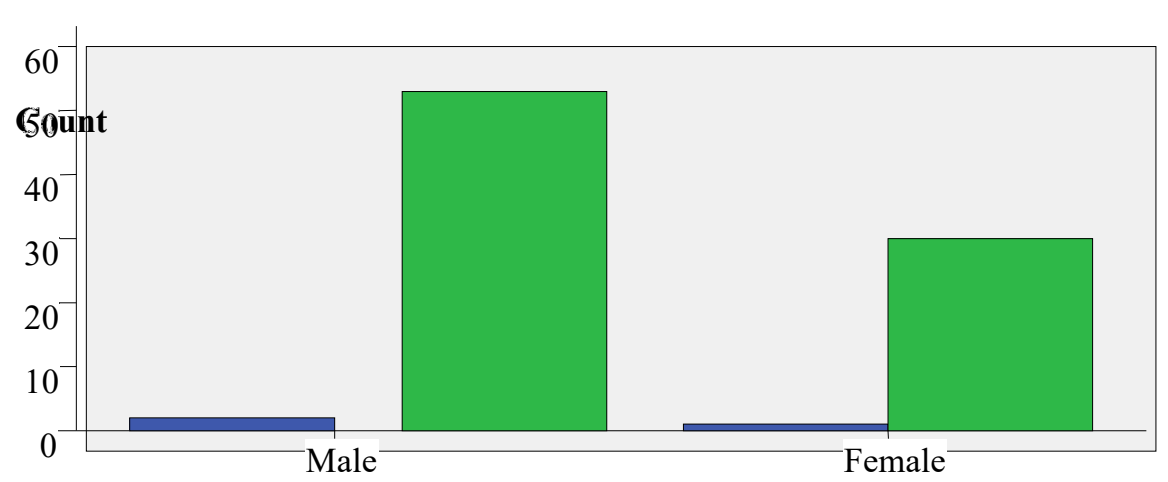

Motivation level

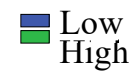

Fig. 4: comparison of Motivation level by sex of the employees

6.3.2 Employees Motivation level by Age of the employees

As mentioned in Table 15 below, the mean values of the motivation index shown as the majority of the employee have higher motivation level in the company (see table 15).

Table 15: Paired Samples Statistics

\begin{tabular}{|c|c|c|c|c|c|}
\hline & & Mean & $\mathrm{N}$ & Std. Deviation & $\begin{array}{l}\text { Std. Error } \\
\text { Mean }\end{array}$ \\
\hline \multirow[t]{2}{*}{ Pair 1} & Age & 35.23 & 86 & 7.115 & .767 \\
\hline & Motivation Index average & .7339 & 86 & .16073 & .01733 \\
\hline
\end{tabular}

Source: own computation

Moreover, the correlation between age of the respondents and their motivation level has shown the presence of positive associations. Meaning, the data analysis confirms as the age of the respondents' increases, motivation level also increases positively. Moreover, the statistical $t$ test confirmed the presence of significant difference among age and motivation level of the employees. That is, motivation levels of the employees are varied across age of the respondents and expected to grow with the age of the respondents (table 16).

Tale 16: Samples Correlations

\begin{tabular}{|ll|l|l|l|}
\hline & $\mathrm{N}$ & Correlation & Sig. \\
\hline Pair 1 & $\begin{array}{l}\text { Age \& Motivation Index } \\
\text { average }\end{array}$ & 86 & .118 & .002 \\
\hline
\end{tabular}

Source: own computation

\subsubsection{Employees motivation level by marital status of the employees}

As shown in table 17 below, Statistically, the chi square result is not confirming the presence of significant difference in motivation of the employees based on their marital status at probability level of .138. 
Table 17: Employees motivation level by marital status of the employees

\begin{tabular}{|c|c|c|c|c|c|c|c|}
\hline & & & Moti & evel & & Chi-S & Tests \\
\hline Marital & atus & frequency & Low & High & Total & & \\
\hline Marital & Single & Count & 2 & 22 & 24 & 3.964 & .138 \\
\hline & & $\%$ & $2.3 \%$ & $25.6 \%$ & $27.9 \%$ & & \\
\hline & Married & Count & & & & & \\
\hline & & $\%$ & $.0 \%$ & $55.8 \%$ & $55.8 \%$ & & \\
\hline & Divorced & Count & 1 & 13 & 14 & & \\
\hline & & & $1.2 \%$ & $15.1 \%$ & $16.3 \%$ & & \\
\hline Total & & Count & & 83 & & & \\
\hline & & $\%$ & $3.5 \%$ & $96.5 \%$ & $100.0 \%$ & & \\
\hline
\end{tabular}

Moreover, as shown in figure 5, all married respondents have high motivation level as compared to single and divorced respondents. Because in both single and divorced respondents they are employees who have low motivation level in the work area.

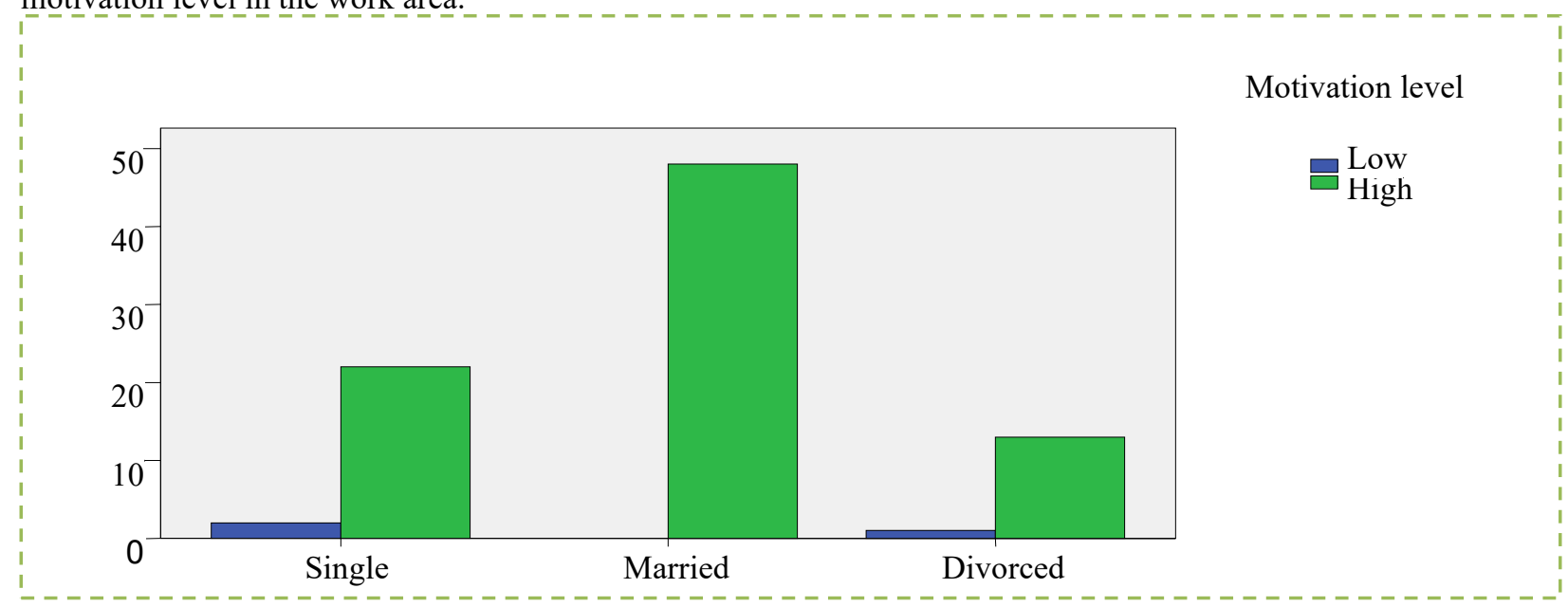

Fig. 5 comparison of marital status by Motivation level

\subsubsection{Employees motivation level by educational status of the employees}

From all the employees included in this study about $96.5 \%$ and $3.5 \%$ of the respondents have high and low motivation level in the organization respectively. Meaning, about $1.2 \%, 20.9 \%, 60.5 \%$, and $14 \%$ of employees who have high motivation level in the work area associate with, educational level of certificate, diploma, $1^{\text {st }}$ degree and $2^{\text {nd }}$ degree respectively.

Whereas, the remaining $2.3 \%$ and $1.2 \%$ of the employees who have $1^{\text {st }}$ degree and $2^{\text {nd }}$ degree have low motivation level in the work area though the chi square statistical test not show the presence of significant difference among the employees motivation level by their educational status. (See table 18 for the details).

Table 18: Motivation level by educational status

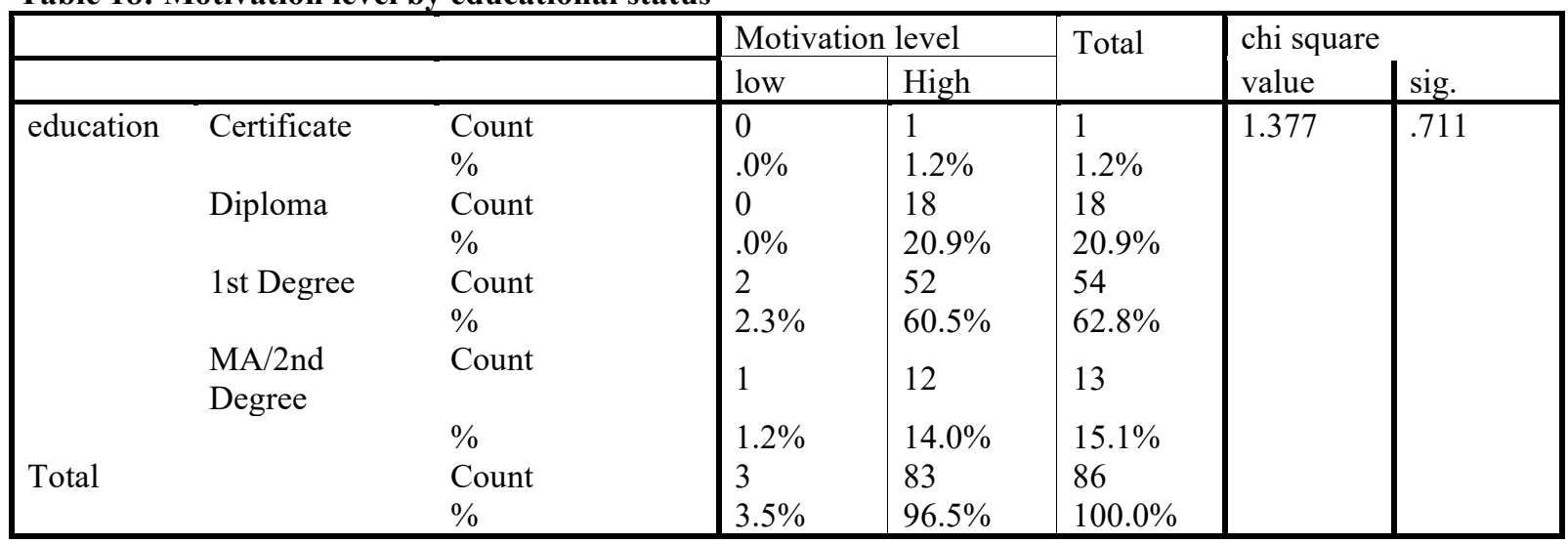

Source: own computation

6.3.5 Employees motivation level by employees' experience

The paired sample correlation shown as there is a positive association between the experience and motivation level 
of the employees. That is, as experience of the employees' increases assumed other things being constant motivation level of the employees also increased though this does not show the difference among the employees at $\mathrm{p}(0.116)$.

Table 19: Paired Samples Correlations

\begin{tabular}{|l|l|l|l|}
\hline & $\mathrm{N}$ & Correlation & Sig. \\
\hline Pair 1 experience \& Motivation Index average & 86 & .171 & .116 \\
\hline
\end{tabular}

Source: own computation

\subsubsection{Employees' motivation level based their salary}

Table 20 displayed, about $96.5 \%$ and $3.5 \%$ of the employees have high and low motivation level respectively. Separately, about $36 \%, 30.2 \%, 16.3 \%$ and $14 \%$ of respondents have monthly salary between $920-2400,2401-$ $3680,3681-7500$ and above 7500 respectively have high motivation. In contrary, about $1.2 \%$ and $2.3 \%$ of the respondents who have salary between 920-2400 and above 7500 have low motivation in the work area respectively. Still, in non monetary analysis the chi square test result not confirmed the presence of significance difference among the employees. In this case also statistically there is not any significant difference among the employees motivation level by their salary gap.

Table 20: Employees' motivation level based on their salary

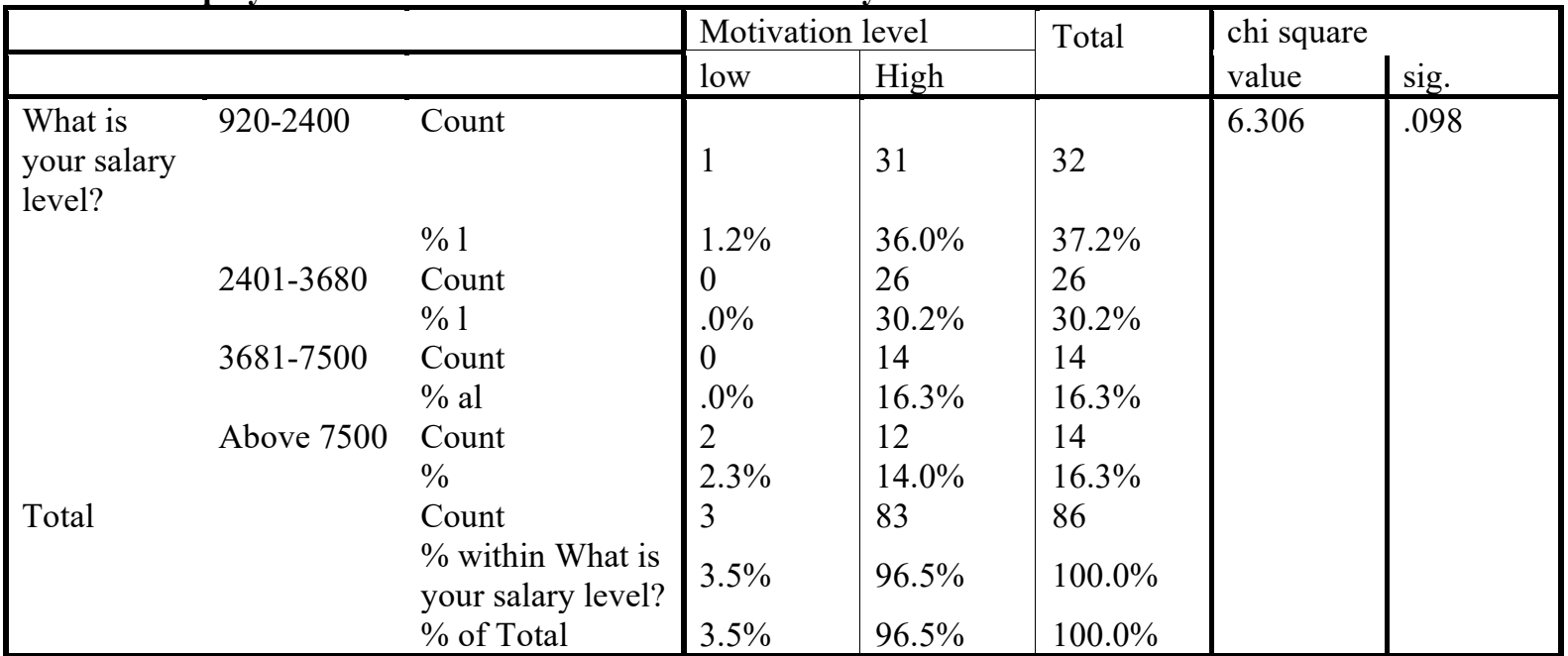

Source: own computation

\subsection{The Relationship between employees' preference and motivation level}

As displayed in table 21, employees' monetary preferences have a mean value of .8216 with +0.14566 standard deviation. Moreover the nonmonetary employees' preferences have a mean value of 0.8119 with +0.15706 standard deviation, comparatively; the mean difference between the two preferences has minimal difference. Generally, the table shows the mean value for the employees motivation level is low compared with the two preferences of the employees

Table 21: Paired Samples Statistics

\begin{tabular}{|ll|l|l|l|l|}
\hline \multirow{2}{*}{ Preferences } & Mean & $\mathrm{N}$ & Std. Deviation & $\begin{array}{l}\text { Std. Error } \\
\text { Mean }\end{array}$ \\
\hline Pair 1 & Monetary preferences & .8216 & 86 & .14566 & .01571 \\
& & .7339 & 86 & .16073 & .01733 \\
Pair 2 & Notivation level & .8119 & 86 & .15706 & .01694 \\
& Monmonetary preferences & .7339 & 86 & .16073 & .01733 \\
\hline
\end{tabular}

Source: own computation

The relationship between the two employees' preferences and motivation level show the presence of positive association with correlation coefficient of 0.326 and 0.271 for monetary and nonmonetary preferences respectively (table 22). That is, as motivation level of the employee increases the employees' monetary and nonmonetary preferences increases directly. Moreover, this analysis confirmed the presence of significant difference among the employees motivation level at probability level of 0.002 and 0.012 for monetary and nonmonetary preferences respectively. 
Table 22: Paired Samples Correlations

\begin{tabular}{|ll|l|l|l|}
\hline & N & Correlation & Sig. \\
\hline Pair 1 & Monetary preferences \& Motivation Index average & 86 & .326 & .002 \\
Pair 2 & Nonmonetary preferences \& Motivation Index average & 86 & .271 & .012 \\
\hline
\end{tabular}

Source: own computation

\section{SUMMARY, CONCLUSION AND RECOMMENDATIONS \\ 7.1. Summary of major findings}

The analysis has shown employees' monetary reward preferences have a mean value of $0.822 \pm 0.146$ standard deviations whereas; the non-monetary employees' preferences have mean value of $0.813 \pm 0.157$ standard deviations respectively. This analysis refers that the mean value of employees' monetary preferences is a little bit greater than the non-monetary employees' preferences. Moreover, the one sample t-statistics reveals the lower and upper limit for both employees' preferences were $0.7903 \& 0.8528$ and $0.7795 \& 0.8474$ respectively for monetary and non-monetary preferences. However, the T-test statistics has shown the absence of statistically significant difference in employees' reward preferences in Ethio Telecom Adama Branch at t- value of .490 ( $\mathrm{P}=.626)$.

The chi-square test results have shown that absence of statically significant variations among the employees' reward preferences based on their sex at $\mathrm{p} \mathrm{(.544)} \mathrm{and} \mathrm{P}(.644)$ monetary and non-monetary reward respectively. The paired t- test result confirms the presence of negative associations between respondents' ages and monetary reward preferences but it is not statistically significant at $\mathrm{p}(.684)$. Whereas, the non-monetary employees reward preference and age of the respondent correlate positively and shown the presence statistically significant difference among the employees' preferences at probability level of $\mathrm{p}$ (.003). As far as concerned employees' reward preference in relation with their working experience, the findings have shown that as experience of the employees' increases in the Ethio Telecom of Adama Branch the need for monetary and non- monetary rewards also increases. Mainly, the relation was very significant at probability level of 0.008 among the experience and non-monetary preferences.

With regarding to marital status the statistical analysis has shown the absence of difference among employees' reward preferences by their marital status at Ethio Telecom -Adama Branch. This was confirmed by very low chi square test value of 1.643 and 1.254 at probability level of $\mathrm{P}(0.440)$ and $\mathrm{P}(0.534)$ for both monetary and nonmonetary employees' preferences respectively. The statistical analysis of the chi -square test also proved that absence of significance difference among employees' reward preference based on their educational qualification and salary level at $\mathrm{p}(0.927)$ and at $\mathrm{P}(0.167)$ respectively.

Unlike the other demographic variables age of the respondents has shown the presence of significant difference among the employees' motivation level. Hence, the correlation between age of the respondents and their motivation level has positive associations at correlation coefficient of 0.118 and probability value of 0.002 .

Finally, the result of statistical test for the association between the two employees' reward preferences and motivation level has shown the presence of positive association at correlation coefficient of 0.326 and 0.271 for monetary and non-monetary preferences respectively. The analysis also proved that the presence of significant difference among the employees' motivation level at probability level of 0.002 and 0.012 for monetary and nonmonetary preferences respectively.

\subsection{Conclusion}

The main objective of the study was to investigate employees' preference towards monetary and non-monetary rewards in relation with their motivation to work at Ethio Telecom -Adama branch. Thus, based on the investigation of this study the following conclusions have made.

This study found that the mean value of employees' monetary reward preferences is a little bit greater than non-monetary reward preferences of employees. Even if the result has shown a difference between the mean value of employees' monetary and non-monetary rewards preference, the difference was not found statistically significant. Therefore, from this, the current study can conclude that both monetary and non-monetary rewards are almost equally preferred by the employees of Ethio-telecom (Adama branch) as instrument for motivation for their work.

Employees' reward preferences based on their demographic characteristics are not shown the presence of significant difference as such in this study except the age of the respondents. Accordingly, the result has confirmed the presence of negative associations between respondents' ages and monetary reward preferences. Meaning, in this analysis as age of the respondents' increases employees' preferences for the monetary rewards decreases though it is not statistically significant. In contrary, the study proved the presence statistically significant difference between the employees' reward preferences and their age. Additionally, the results also have shown that positive association between the age of respondent \& their non-monetary reward preference meaning that as age of the employees increases, demand for non-monetary reward also increases at Ethio-Telecom (Adama branch).

The statistical analysis has shown that age of the respondents has shown the presence of significant difference 
among the employees' motivation level in opposite to others demographic characteristics. Hence, the correlation between age of the employees and their motivation level has positive associations. Meaning, as the age of the employees' increases, their motivation level also increases positively. Generally, the study concludes that motivation levels of the employees are varied across age of the respondents and expected to grow with the age of the respondents.

Lastly, as far concerned the analysis of employees' level of motivation in relation with two rewards preference, the study concludes that the presence of positive association between employees' level of motivation and employees' rewards preferences. Thus, as motivation level of the employee increases, the employees' monetary and non-monetary reward preference also increases directly and the vice versa and the study also conclude that the presence of significant difference of between employees' level of motivation and monetary and non-monetary reward rewards preferences at Ethio-telecom (Adama branch).

\subsection{Recommendation}

On the basis of the findings of the study and conclusion made, the following recommendations were forwarded.

1. As long as this study revealed that there was no any statistically significant difference among reward preference of Ethio-Telecom (Adama -branch) employees, the management of Ethio-Telecom should equally emphasize on the importance of both monetary and non-monetary rewards while designing its reward system. Meaning that, the finding this study has shown that both monetary and non-monetary rewards found to be very essential in motivating the work force of the company for better outcome. Therefore, the management should provide both monetary and non-monetary rewards for its employees in order to enhance better their motivation to work.

2. Since the data analysis confirmed the presence of positive associations between employees' age and nonmonetary reward preferences as well as the presence of statistically significant difference among the employees' age and non- monetary reward preferences, the management team of Ethio -Telecom at Adama branch should emphasis on providing non-monetary rewards as the age of employees increases so as to retain and motivate them for superior outcome.

3. As the current issues of identifying employees' preferences and motivation level has paramount importance for attainment of objective of organization, timely assessments should be undertaken in order to intensify the outcome of the employees and as well as offering different mechanisms of motivation and encouragement have a positive impact on employees' performance, it should be grown and undertaken continuously in the organization to boost the motivation level of the employees.

4. Though the study result show inadequacy of motivation on few employees in the Ethio Telecom of Adama branch, remedial activities should be undertaken to enhance the motivation level of all the employees.

5. Generally, more tasks should be done to maximize the employees' motivation level and to meet the Gross and Transformational Plan of the country, in accordance with the stated objective of the Ethio Telecom Adama Branch.

\subsection{Recommendations for further research}

As far as the samples size is concerned the current study has undertaken small sample size. Therefore, conducting similar studies at others public organizations with a larger sample size would be highly desirable and seems appropriate to generalize the study.

\section{REFERENCES}

Admin. (2012, 3 12). An Efficient Motivation Questionnaire for Employees. Retrieved from http://surveysworldwide.com/en/available_questionnaires

Armstrong, M. (2007). Handbook of human resource management (10th edition ed.). London and Philadelphia.

Arnolds, C., \& Venter, D. (2007). The strategic importance of motivational rewards for lower-level employees in the manufacturing and retailing industries. SA Journal of Industrial Psychology, 33 (3), 15-23.

Ary, D., Jacobs, 1. c., \& Aszayieh, A. (1990). Introduction to research in education. Holt, Rinehart \& Wnston.

Aworemi, J. R., Abdul-Azeez, I. A., \& Durowoju, S. T. (2011). An Empirical Study of the Motivational Factors of Employees. International Journal of Economics and Finance, Vol. 3, No. 5, (ISSN 1916-971X,E-ISSN 1916-9728), p.227-233.

Best, J. W., \& Kahn, J. V. (1993). Research in education (8 edition ed.). Allyn and Bacon.

Best, J. W., \& Kahn, J. V. (2005). Research in Education (10 edition ed.). Pearson.

Carrell, M., Elbert, N., \& Hatfield, R. (1995). Human resource management:Global strategies for managing a diverse workforce (5th edition ed.). New Jersey: Prentice-Hall, Inc.

Cennamo, L., \& Gardner, D. (2008). Generational differences in work values, outcomes and person- organisation values fit. Journal of Managerial Psychology, 23(8), 891- 906.

Chernyshenko, O. .., \& Lawton, K. ((2008)). Examining determinants of employee benefit preference: Joint 
seffects of personality, work values, and demographics. Asia Pacific Journal of Human Resources, 46(2), $220-240$.

Cropanzano, Kacmar, \& Bozeman. (1995). The social setting of work organizations: Politics, justice, and support:Managing the Social.

Danish, R. Q., \& Usman, A. (2010). Impact of Reward and Recognition on Job Satisfaction and. International Journal of Business and Management, Vol. 5, No. 2 , 159-165.

Erbaş, A., \& Arat, T. (2012). The Effect of Financial and Non-financial Incentives on Job Satisfaction. International Business Research, Vol. 5, No. 10.

Ethio-Telecom Adama branch. (2013). Human resource department.

Goodman, N. (2012, November). Inside employee motivation: Does money really make a difference? Retrieved from http://www.entrepreneur.com/blog/225041

Google \& Incentives. (2012, March ). A Literature review to better understand the motivation of Google employees.

Gupta, N., \& Mitra, A. (1998, Autumn). The Value of Financial Incentives. ACA Journal , 58-66.

Hafiza, N. S., Shah, S. S., Jamsheed, H., \& Zaman, K. (2011). Relationship between rewards and employee's motivation in the nonprofit organizations. Business Intelligence Journal, Vol.4 No.2, 327-334.

Hedge, J., Borman, W., \&\& Lammlein, S. ( 2006). The aging workforce:Realities, myths, and implications for organizations. Washington, DC: American .

Hossain, M. K., \& A. H. (2012). Factors affecting employee's motivation in the fast food industry. Research journals of economics, business and ICT, 5, 21-30.

Hsieh, Y., \& Chen, H. (2006). Key trends of the total reward system in the 21 st century. Compensation and Benefits Review, 38(6), 64-70.

James E. Barttlett, I., Kotrlik, J. W., \& Higgins, C. C. (2001). Organizational Research: Determining Appropriate Sample Size in Survey Research. Information Technology, Learning, and Performance Journal, Vol. 19, No. $1,, 43-50$.

Kim, D. ( 2006). Employee Motivation: “Just Ask Your Employees”. Seoul Journal of Business, 12 (1), 20-35.

Kirstein, M. (2010). The role of motivation in Human Resource Management:Importance of motivation factors among future business persons. (maters thesis , Aarhus University).

Knowledge@Wharton. (2011). The problem with financial incentives and what to do about it. Wharton School of the University of Pennsylvania. Knowledge@Wharton.

Konrad, A., Ritchie, J., Lieb, P., \& Corrigall, E. (2000). Sex differences and similarities in job attribute preferences. A meta-analysis. Psychological Bulletin, 126(4), 593-641.

Lægaard, J., \& Bindslev, M. (2006). Organizational theory. Ventus Publishing ApS.

Lameck, W. U. ( (2011)). Non Financial Motivation as Strategy for Improving. International Journal of Management \& Business Studies, 1 (4), 57-63.

Manzoor, Q.-A. (2012). Impact of employees motivation on organizational effectiveness. business management and strategy, 3 ( 1), International Journal of Management \& Business Studies

Muhammad, M., Maria, M., \& Saqlain, M. (2011). Association between Reward and Employee motivation. European Journal of Humanities and Social Sciences, 5 ( 1), 166-178.

Munk, R. S. (2012). A theoretical discussion Of the effect of intrinsic and extrinsic motivation. ( bachelor thesis, Aarhus school of business).

Nazir, T., Shah, S. F., \& Zaman, K. (2012). Literature review on total rewards: An international perspective. African Journal of Business Management, 6(8), 3046-3058.

Neuman, W. L. (2007). Basics of social research:Qualitative and quantitative approach (2nd edition ed.). Copyright (C) 2007, 2004 Pearson Education, Inc.

Nienaber, R., Bussin, M., \& Henn, C. (2011). The relationship between personality types and reward preferences. Acta Commercii, 11(2), 56-79.

Nujjoo, \& Meyer. (2012). The relative importance of different types of rewards for employee motivation and commitment in South Africa. SA Journal of Human Resource Management, 10(2), 10(2), Art. \#442,10 pages.

Okojie, V. ((2009)). Rewards Policy and Employee Motivation. Samaru Journal of Information Studie, 9 (2), 33 45.

Pepermans, R. (2012). The mediating role of job satisfaction in the relationship between reward satisfaction, turnover intention and work effort across occupational status. Faculty of economics, political and social sciences and solvay business school master of science in managemen.

Qureshi, M. I., Zaman, K., \& Shah, I. A. (2010). Relationship between rewards and employee's performance. Journal of International Academic Research, 10 (2), 19-28.

Rashid, S. (2012). Work Motivation Differences between Public and Private Sector. American International Journal of Social Science, Vol. 1 No. 2, 24-30.

Robbins, S. P. (1996). Organizational behavior ( 7th editions ed.). Mainland, China: Tsinghua university and 
prentice-Hall. .

Roberts, R. L. (2005). The relationship between rewards, recognition and motivation at an insurance company. university of the western cape, Industrial psychology.

Rynes, S. L., Gerhart, B., \& Minette, K. A. (2004). The Importance of Pay in employee:Discrepancies between What People say and what they do. Human Resource. 43 (4), 381-394.

Sajuyigbe., A., Bosede, O., \& Adeyemi, M. (2013). Impact of reward on employees' performance. International Journal of Arts and Commerce, 2, 27-32.

Schuldes, C. H. (2006). Employee preferences for pay system criteria. Capella University.

Singh, Y. k. (2006). Fundamental of research methodology and statistics. New age international (P) limited publisher.

Snelgar, R. J., Renard, M., \& Venter, D. (2013). An empirical study of the reward preferences of South African employees. SA Journal of Human Resource Management/SA Tydskrif vir Menslikehulpbronbestuur, 11(1), Art. \#351, 14.

Steers, R. M., Mowday, R. T., \& Shapiro, D. L. (2004). The future of work motivation theory. Academy of management review, Vol. 29 No. 3, 379-387.

Tanasiuk, E., \& Islam, S. (2012). Do people always respond to incentives? Experience in data gathering through face to face interviews. ASBBS Annual Conference: Las Vegas 893, 19 (1), pp. 890-898.

Tande, C., \& Hill, B. (2006). Total rewards: The employment value proposition. 10(6), 19-22.

Tippet, J., \& Kluvers, R. (2009). Employee Rewards and Motivation. International journal of business management, 4(3), 7-14.

Ude, U., \& Coker, M. A. (2012). IOSR Journal of Business and Management (IOSRJBM) ISSN: 2278-487X Volume 1, Issue 4, 1 (4), 32-39.

Yudhvir, \& Sunita. (2012). Employee's motivation: theories and perspectives. asian journal of multidimensional research, 1 ( 2), 56-64. 